\title{
The impact of the creative environment on the creative person, process, and product
}

\author{
Soraia Garcês, Margarida Pocinho ${ }^{1}$ \\ University of Madeira, Funchal, Portugal \\ Saul Neves de Jesus, João Viseu \\ University of Algarve, Faro, Portugal
}

\section{ABSTRACT}

Creativity is a highly complex concept, studied through different perspectives and evaluated by numerous instruments. Despite its conceptual and methodological diversity, the Rhodes' multidimensional theory continues to be one of the main references in the study of creativity. Based on this theory, this study intended to observe the impact of the creative environment on the creative person, process, and product through a sample of 215 college students. Results suggest a significant influence from the creative environment on the creative process and product. Participants from the social sciences and arts performed better on the creative process and product, respectively. No statistically significant interaction effects were found regarding gender and the creative environment. However, age presents a control effect over the relationship between the creative environment and the plastic arts. Practical and educative implications are discussed.

Keywords: creativity; creative environment; creative person; creative process; creative product.

\section{RESUMO - O impacto do ambiente criativo na pessoa, processo e produto criativo}

A criatividade é um conceito complexo que tem sido abordado segundo diversas perspetivas teóricas e múltiplos instrumentos de avaliação. Não obstante, a diversidade conceptual e metodológica existente, a teoria multidimensional de Rhodes continua a ser uma das principais referências para o seu estudo. Com base nessa teoria, este estudo observa o impacto do ambiente criativo na pessoa, no processo e no produto criativo, numa amostra de 215 estudantes universitários. Os resultados indicam uma influência significativa do ambiente criativo sobre o processo e produto criativo. Os participantes das ciências sociais e artes obtiveram valores superiores nas dimensões Processo criativo e Produto criativo, respetivamente. Não foram encontrados efeitos de interação significativos entre o gênero e ambiente criativo, contudo a idade apresenta um efeito interativo na relação entre o ambiente e as artes plásticas. Implicações práticas e educativas são discutidas.

Palavras-chave: criatividade; ambiente criativo; pessoa criativa; processo criativo; produto criativo.

\section{RESUMEN - El impacto del ambiente creativo en la persona, processo y produto creativo}

La creatividad es un concepto complejo que se ha abordado desde diferentes perspectivas teóricas y múltiples herramientas de evaluación. A pesar de la diversidad conceptual y metodológica existente, la teoría multidimensional de Rhodes sigue siendo una referencia importante para lo estudio de la creatividad. Basándose en esta teoría, este estudio intenta observar el impacto del ambiente creativo en la persona, proceso y producto creativo, donde participaron 215 estudiantes universitarios. Los resultados indican una influencia significativa del ambiente creativo sobre el proceso y producto creativo. Los participantes de las ciencias sociales y las artes obtuvieran valores más altos en lo proceso y producto creativo, respectivamente. Ningún efecto de interacción significativo ha sido encontrado entre el género y ambiente creativo. Todavía, la edad ha presentado un efecto controlador en la relación entre el ambiente y las artes plásticas. Se discuten las implicaciones prácticas y educativas.

Palabras clave: creatividad; ambiente creativo; persona creativa; proceso creativo; producto creativo.

The study of creativity has been put aside for a long time, but a Guilford's speech, during the 1950s, led creativity to become a field of interest for the scientific community (Beghetto \& Kaufman, 2009; Runco, 2007). Today, we can find a large number of theories that try to explain it (Batey \& Furnham, 2006; Csikszentmihalyi,
2009; Kozbelt, Beghetto, \& Runco, 2010; Sternberg \& Lubart, 2009; Torrance, 1977; Wechsler, 2008), however a consensus regarding this concept is yet to be established.

An unequivocal creativity definition is still not clear and truth be told a wide range of perspectives shaped its 
conceptualization (Batey \& Furnham, 2006). As stated by Batey and Furnham (2006, p. 358), "each approach inevitably concentrates on the issue of creativity differently, devising its own theories, methods, and investigative paradigms. Therefore, this neglected field is also deeply fragmented, indicating the need for a comprehensive review" (p. 358). The Guilford Structure of Intellect Model shed some light on creativity, as many other researchers, such as Paul Torrance, Alex Osborn, and Mel Rhodes, some of them still influence recent works as seen, for example, in the work of Murdock and KellerMathers (2008) who used the Torrance's framework. These and other authors contributed tremendously to the foundation of the study on creativity and as KellerMathers (2011) emphasized some of the current work on this concept arises from past works and perspectives of the aforementioned authors.

Rhodes (1961) 4 P's categorization is one of the most acknowledged models and one of the first to state that creativity is a confluence of four aspects: (a) the creative person; (b) the creative process; (c) the creative product; and (d) the press. As Rhodes (1961) affirmed, creativity describes a phenomenon where an individual develops new products, with implicit cognitive thinking, and where there is an environment that potentiates that creation. As stated by Keller-Mathers (2011), the work of Rhodes is very useful to explore creativity in the scope of teaching and learning. More recently, Jordanous (2015) in a new field of the study of creativity, computational creativity, considered that this new area should be explored through the angles of the 4 P's, person, product, process, and press/environment. Nevertheless, these four concepts have been studied separately (Isaksen, 1995).

The studies surrounding the creative person have been focusing, especially, on the research about the personality characteristics of creative individuals. On a simple literature analysis we can find the mention of characteristics, such as: (a) fluency; (b) flexibility; (c) elaboration; (d) originality; (e) curiosity; (f) self-esteem; (g) an "open mind"; (h) independence; (i) confidence; (j) motivation; (k) imagination; (l) persistence, among others (Carson, 1999; Davis, 1999; Harrington, 1999; Plucker \& Renzulli, 2009; Wechsler, 2008).

Researches on the creative process can adopt different approaches. Wallas (1926) was one of the first to describe the creative process as a sequence of stages: (a) preparation; (b) incubation; (c) illumination; and (d) evaluation. On the other hand, we can find theories emphasizing the Creative Problem Solving Model, where Osborn (1952) is one of its' first representatives. A relatively new way of approaching the creative process is the Geneplore model, where this aspect is seen as having two main processes: (a) exploratory; and (b) generative (Ward \& Kolomyts, 2010; Ward, Smith, \& Finke, 2009).
Studies regarding the creative product focus on the characteristics that make a product creative. One of the main studies on this field was developed by Susan Besemer (Puccio, Treffinger, \& Talbot, 1995) and Treffinger in 1981 (O'Quin \& Besemer, 1999). They emphasized that to evaluate a creative product, three main characteristics should be present: (a) novelty; (b) resolution; and (c) elaboration/synthesis (O'Quin \& Besemer, 1999). Often, studies on this field also focus on the evaluation of the product and what makes it creative, so we can find a large number of different tools, like inventories, who help us to evaluate a creative product (Morais \& Azevedo, 2009; O'Quin \& Besemer, 1999).

Finally, we emphasize the press which refers to: (a) the "place" where the subject is; (b) where the product is produced; or (c) where the creative process occurs (Scritchfield, 1999). Isaksen (1995) affirmed that it involves the comprehension of a set of factors, namely individual and contextual (e.g., climate and culture). Soliman (2005) said that the press must be seen as the relationship between the individuals and their environments, this is important to assess the environmental conditions that inhibit or potentiate creativity. Also, many aspects can influence the development of creativity, such as availability of resources and expertise (Keller-Mathers, 2011). Studying creativity through the press approach implies that two directions must be considered: (a) the way the environment influences the person who creates and accepts its work; and (b) the person who creates and is criticized on its products (Jordanous, 2015), due to this situation many researchers underlined the relevance of culture (Amabile, Conti, Coon, Lazenby, \& Herron, 1996; Lee \& Kim, 2010; Wechsler, 2006).

Creativity is a natural resource of human beings, thus it is not only a cognitive process, nor is it exclusive to some people. However, many factors contribute to its development (Oliveira \& Alencar, 2007). According to Batey and Furnham (2006), those who study the creative environment look to understand the physical and social circumstances in which creativity is more likely to develop. Promoting creativity is associated with the interactions of a person with its family, school, and society. So, a friendly environment to creativity development is related with the quality of those interactions and the life experiences people have in those contexts. Thus, school is an important place to the development of creative skills (Ribeiro \& Fleith, 2007). Alencar and Fleith (2010) suggested that higher education should have the development of creativity in students as one of its fundamental goals. As stated by Oliveira and Alencar (2007), higher education lacks in the promotion and development of creativity. Ribeiro and Fleith (2007) stated that higher education does not offer tools to allow teachers to make use of creativity in the classroom. Research has shown that the study of factors that surround the development of creativity in higher education are scarcely discussed. 
Higher education is complex and sometimes there are resistances from teachers and students, structural, processual, and cultural elements, time and resources, and governmental policies, which act as possible barriers to creativity development (Alencar \& Fleith, 2010).

Keller-Mathers (2011) referred to three steps that are needed to enhance the development of creative learning and teaching in higher education: (a) recognize the need of creativity and problem solving skills; (b) acknowledge the importance of creativity for oneself and others; and (c) understand the different ways to develop and nurture creativity. Edwards, McGoldrick, and Oliver (2006) discovered that teachers are apprehensive to take on risks in a culture that does not accept failure and that they lack resources, especially time. Fryer (2006) noted that: (a) work overload; (b) inadequate preparation time for classes; (c) large class sizes; and (d) inadequate resources were some of the inhibiting factors to the development of creativity in higher education. Alencar and Fleith (2008) found that universities and course conditions, the way the education process has been conducted, bad quality education, and the gap between university and job market limit the creative capacity.

Bahia and Nogueira (2005), in an exploratory study with college students, discovered that humanities students displayed a greater performance on verbal creativity, also the arts students revealed a more elaborated work on the figurative tasks, and the sciences students performed better both on the figurative and verbal tasks. The verbal tasks needed a conceptual and metaphorical thinking, present in the humanities field, but those tasks also appealed to curiosity and hypotheses formulation, aspects needed in the sciences environment. The figurative tasks pointed to problem solving and the organization of incomplete forms, characteristic aspects of the arts' field. The researchers stated that each of the groups, humanities and sciences, showed a certain level of specialization on their field of knowledge (Bahia, 2008; Bahia \& Nogueira, 2005). Also in this line of thought, Martim (2007) affirmed that creativity in arts differs from creativity in sciences, however we should not stereotype that creativity is only found in arts.

For Simonton (2004) the main difference between these groups is the fact that the scientists work has more restricted conditions than the artists'. Cashdan and Welsch (1966) found no significant differences between students, with high creativity levels, in the arts and sciences areas. Morais, Almeida, and Azevedo (2014), while mentioning Cropley and Cropley (2009) study, stated that these researchers found that individuals from the arts field are more open to a creative expression that challenges social norms, accepting more risks and originality; sciences individuals, tend to value more creative problem solving; and foreign languages individuals tend to involve less creative endeavors comparing to arts and sciences. Thus, different knowledge, skills, or expectations are associated with the creative expression in different fields. According to Baer (2011), creativity is influenced by domain-specific and universities have that differentiation present in the courses and fields of study that are presented to their students (Morais et al., 2014).

Jordanous (2015) lets us understand that from the 4 P's conceptual frame we can build novel viewpoints to different ideas of creativity and most of this framework has been embraced as it was the first to be considered by scholars. Still, accordingly to Jordanous (2015) studying creativity by the 4 P's framework allows us to pay attention to four crucial features: the person who creates products, the process that occurs, and the press that influences creative development. The 4 P's framework presents different views of creativity and aggregates them in a holistic model (Jordanous, 2015).

Our study aimed to understand the possible influence of the creative environment over the creative person, process, and product. As Scritchfield (1999) said, the press can refer to the "place" where the person is, in this study we considered this "place" (i.e., the creative environment variable) as the field of academic studies of the individuals who took part in the research. Literature has emphasized that the creative environment is a key factor for creative expression, however few studies have been developed to understand if the creative environment is indeed related to the person, the process, and the product considered creative. Also, few studies have been made in this field. This exploratory study intends to bring new insights about the topic as a means for enriching the knowledge on the creative environment.

\section{Method}

\section{Participants}

The 215 participants of this study were students from Madeira and Algarve Universities with ages ranging from 18 to 56 years old $(M=25.01 ; S D=8.03)$. The sample was composed by $80.4 \%$ of females $(n=172)$ and $19.6 \%$ of males $(n=42), 80 \%$ came from Madeira's University $(n=172)$ and $20 \%$ from Algarve's University $(n=43)$. Participants from the social sciences were $71.2 \%(n=153)$ and from the arts were $28.8 \%(n=62)$. Concerning age, $60.9 \%(n=92)$ of the participants from the social sciences had 25 years old or less and 39.1\% $(n=59)$ were more than 25 years old. In the arts field, $83.9 \%(n=52)$ had, at the time, 25 years old or less and $16.1 \%(n=10)$ were more than 25 years old. Regarding gender, in the case of social sciences, $89.5 \%(n=136)$ were females and $10.5 \%(n=16)$ were males, and, in the arts, $58.1 \%(n=36)$ were females and $41.9 \%(n=26)$ were males.

\section{Instruments}

Three instruments were used on this research: (a) the creative personality scale (CPS); (b) the creative 
behavior inventory - short form (CBI); and (c) the insight problem solving test (IPST). The CPS was developed in prior researches (Garcês et al., 2015; Jesus et al., 2011) and presented a Cronbach's alpha of .91. It is composed by 30 items (I am an optimistic or I am selfconfident) that addressed the creative personality within a Likert scale ranging from 1 (strongly disagree) to 5 (strongly agree). On the present study the internal consistency was .85 .

The IPST was created by Morais (2001) and presented a Cronbach's Alpha of .72. It is composed by eight insight problems (A man who lived in a small town took to the altar 20 different women of the same town. All are still living and he never divorced any of them. In this town polygamy is unlawful. How is this possible?) and it was used, in this research, as a measure of the creative process (Morais, 2003). The IPST evaluated the insight ability of individuals and the obtained results were not mechanic. There is a need to evaluate if an individual did change his/her process of thought while resolving the problem through a description of its thinking process. The Cronbach's Alpha value of the IPST in the present research was .68.

The CBI was originally developed by Dollinger (2011) and was recently adapted to the Portuguese population (Garcês, 2013; Garcês, Pocinho, \& Jesus, 2012). It is composed by 28 items that refer to the creative behaviors that may occur on a daily basis (Painted an original picture (excluding school or university course work) or Prepared an original floral arrangement). On its' Portuguese form it presented a Cronbach's alpha of .88 and four factors: (a) plastic arts $(\alpha=.76)$; (b) literature ( $\alpha=.76)$; (c) visual arts $(\alpha=.77)$; and (d) crafts $(\alpha=.77)$. On this study the reliability value was .86 .

\section{Procedures}

The battery of tests was administered at Madeira and Algarve Universities with the help of teachers who agreed on giving class time to the instruments' application. The research objectives were explained to the participants, as well as the fact that their participation was voluntary and that the obtained results were confidential. The creative environment variable was considered to be the field of academic studies of the participants and defined as a dichotomous variable. So we distinguished between two main areas: (a) social sciences; and (b) arts. social sciences included students from Basic Education and Psychology, and arts included students from Art and Multimedia, and Design. This decision was made because the creative environment can be understood as the place where the creative process occurs, and the course or field of academic study of the participants is the "place" where individuals are influenced by many aspects, such as teachers, peers, physical environment, domain-specific knowledge, but where the students share a wide range of common experiences that may influence their creative development.

\section{Results}

A general linear model was conducted to perform the analysis, namely a multivariate analysis of variance (MANOVA). The creative environment was established as a fixed factor and the remaining variables as dependent (the creative person, process, and product). Gender was also examined for a possible interaction effect. Box's $M$ value was not statistically significant $(p=.120)$ so equality of covariances was assumed. For the next set of analyzes Pillai's Trace $(V)$ was used, as recommended by Field (2005).

The creative environment alone was statistically significant $\left(V=.32, F(6,160)=12.61, p=.000, \eta_{p}{ }^{2}=.32\right)$ which implies that $32 \%$ of the variance was accounted by the creative environment. Separate ANOVA's were conducted revealing significant results for the creative process and the visual arts as shown in Table 1. Social sciences performed better in the creative process $(M=3.37$; $S D=2.19)$ when compared to the arts $(M=2.60$; $S D=1.78)$. Arts participants achieved better results in the visual arts $(M=8.12 ; S D=3.67)$ comparatively to the social sciences $(M=4.63 ; S D=3.66)$. Levene's test revealed homogeneity of variances for the creative person $(F=0.58, p=.628)$, plastic arts $(F=2.26, p=.083)$, literature $(F=0.59, p=.622)$, visual arts $(F=1.53, p=.208)$, and crafts $(F=0.39, p=.764)$, but not for the creative process $(F=2.94, p=.035)$.

The interaction between gender and the creative environment is non-significant $(V=.04, F(6,160)=0.980$, $p=.441, \eta_{p}^{2}=.04$ ).

Age, considered as a continuous variable, was introduced in the model as a covariate, and we performed a multivariate analysis of covariance (MANCOVA). Box's $M$ value was again non-significant with a $p$-value of .120. The creative environment variable continued to be statistically significant $(V=.29, F(6,158)=10.96$, $p=.000, \eta_{p}{ }^{2}=.29$ ) which hint that age is not controlling the interaction between the creative environment and creative person, process, and/or product. However, as the results showed, there was a decrease on the F-value and partial eta squared. This prompted us to analyze the univariate effects. The creative process and visual arts continue to be statistically significant, but after controlling age, the plastic arts revealed a significant result, as shown in Table 2. Again, social sciences performed better at the creative process $(M=3.38 ; S D=2.20)$ than arts $(M=2.60 ; S D=1.78)$. Arts participants achieved better results in the visual arts $(M=8.12 ; S D=3.67)$ than social sciences $(M=4.62 ; S D=3.68)$, and also on the plastic arts $(M=3.82 ; S D=3.59)$ comparatively to the social sciences $(M=2.67 ; S D=3.15)$. However, the interaction between gender and the creative environment when controlling age, continued to be non-significant $(V=.04, F(6$, 158) $=1.02, p=.412, \eta_{p}{ }^{2}=.04$ )

Homogeneity was achieved for all variables, creative person $(F=1.11, p=.347)$, plastic arts $(F=1.86, p=.138)$, 
literature $(F=0.61, p=.609)$, visual arts $(F=1.47$, $p=.223)$, crafts $(F=0.31, p=.820)$, and creative process $(F=2.26, p=.083)$.

When examining the results it is possible to observe that the creative environment variable does have an impact on the creative process and product, but not on the creative person. Gender does not seem to establish an interaction effect with the creative environment, but age can be acknowledged as a possible "confounding variable" on the creative product, namely on the plastic arts.

Table 1

Creative Environment Effect

\begin{tabular}{|c|c|c|c|c|c|c|c|}
\hline $\mathrm{DV}^{\mathrm{a}}$ & $\mathrm{IV}^{\mathrm{b}}$ & $M^{c}$ & $\mathrm{SD}^{d}$ & $F$ & $d f^{e}$ & Sig. & $\eta_{p}^{2 f}$ \\
\hline \multirow{2}{*}{ Creative process } & Social sciences & 3.37 & 2.19 & \multirow{2}{*}{5.23} & \multirow{2}{*}{1} & \multirow{2}{*}{$.023^{*}$} & \multirow{2}{*}{.031} \\
\hline & Arts & 2.60 & 1.78 & & & & \\
\hline \multirow{2}{*}{ Creative person } & Social sciences & 116.68 & 15.22 & \multirow{2}{*}{0.13} & \multirow{2}{*}{1} & \multirow{2}{*}{.715} & \multirow{2}{*}{.001} \\
\hline & Arts & 115.64 & 13.82 & & & & \\
\hline \multirow{2}{*}{ Plastic arts } & Social sciences & 2.68 & 3.14 & \multirow{2}{*}{2.76} & \multirow{2}{*}{1} & \multirow{2}{*}{.099} & \multirow{2}{*}{.016} \\
\hline & Arts & 3.82 & 3.59 & & & & \\
\hline \multirow{2}{*}{ Literature } & Social sciences & 5.68 & 3.63 & \multirow{2}{*}{3.24} & \multirow{2}{*}{1} & \multirow{2}{*}{.074} & \multirow{2}{*}{.019} \\
\hline & Arts & 4.52 & 3.00 & & & & \\
\hline \multirow{2}{*}{ Visual arts } & Social sciences & 4.63 & 3.66 & \multirow{2}{*}{30.78} & \multirow[b]{2}{*}{1} & \multirow{2}{*}{$.000^{*}$} & \multirow{2}{*}{.157} \\
\hline & Arts & 8.12 & 3.67 & & & & \\
\hline \multirow{2}{*}{ Crafts } & Social sciences & 7.84 & 4.32 & \multirow{2}{*}{0.00} & \multirow{2}{*}{1} & \multirow{2}{*}{.989} & \multirow{2}{*}{.000} \\
\hline & Arts & 6.32 & 3.94 & & & & \\
\hline
\end{tabular}

Note. ${ }^{a}$ Dependent variables; ${ }^{\mathrm{b}}$ Independent variable (creative environment); ${ }^{\mathrm{c}}$ Mean; ${ }^{\mathrm{d}}$ Standard deviation; ${ }^{\mathrm{e}}$ Freedom degrees; ${ }^{\text {f }}$ Partial eta squared; ${ }^{*} p<.05$

Table 2

Creative Environment Effect with Age as a Covariate

\begin{tabular}{|c|c|c|c|c|c|c|c|}
\hline $\mathrm{DV}^{\mathrm{a}}$ & $\mathrm{IV}^{\mathrm{b}}$ & $M^{c}$ & $S D^{d}$ & $F$ & $d f^{e}$ & Sig. & $\eta_{p}^{2 f}$ \\
\hline \multirow{2}{*}{ Creative process } & Social sciences & 3.38 & 2.20 & \multirow{2}{*}{9.46} & \multirow{2}{*}{1} & \multirow{2}{*}{$.002^{*}$} & \multirow{2}{*}{.055} \\
\hline & Arts & 2.60 & 1.78 & & & & \\
\hline \multirow{2}{*}{ Creative person } & Social sciences & 116.58 & 15.24 & \multirow{2}{*}{1.67} & \multirow{2}{*}{1} & \multirow{2}{*}{.199} & \multirow{2}{*}{.010} \\
\hline & Arts & 115.64 & 13.82 & & & & \\
\hline \multirow{2}{*}{ Plastic arts } & Social sciences & 2.67 & 3.15 & \multirow{2}{*}{4.69} & \multirow{2}{*}{1} & \multirow{2}{*}{$.032^{*}$} & \multirow{2}{*}{.028} \\
\hline & Arts & 3.82 & 3.59 & & & & \\
\hline \multirow{2}{*}{ Literature } & Social sciences & 5.69 & 3.64 & \multirow{2}{*}{3.66} & \multirow{2}{*}{1} & \multirow{2}{*}{.058} & \multirow{2}{*}{.022} \\
\hline & Arts & 4.52 & 3.00 & & & & \\
\hline \multirow{2}{*}{ Visual arts } & Social sciences & 4.62 & 3.68 & \multirow{2}{*}{23.96} & \multirow{2}{*}{1} & \multirow{2}{*}{$.000^{*}$} & \multirow{2}{*}{.128} \\
\hline & Arts & 8.12 & 3.67 & & & & \\
\hline \multirow{2}{*}{ Crafts } & Social sciences & 7.86 & 4.33 & \multirow{2}{*}{.27} & \multirow{2}{*}{1} & \multirow{2}{*}{.602} & \multirow{2}{*}{.002} \\
\hline & Arts & 6.32 & 3.94 & & & & \\
\hline
\end{tabular}

Note. ${ }^{a}$ Dependent variables; ${ }^{\mathrm{b}}$ Independent variable (creative environment); ${ }^{\mathrm{c}}$ Mean; ${ }^{\mathrm{d}}$ Standard deviation; ${ }^{\mathrm{e}}$ Freedom degrees; f Partial eta squared; ${ }^{*} p<.05$ 


\section{Discussion}

We aimed to understand if the creative environment does influence the creative person, process, and/or product. We adopted the field of academic study of the participants as the creative environment, because we believe that the experiences that one goes through in a university course can influence their creative development, as Ribeiro and Fleith (2007) mentioned school is a place that can influence creativity.

Overall, the multivariate analysis performed showed that the creative environment influences the creative process and product. Social sciences participants were better in the creative process and arts participants performed better in the creative product. As Morais et al. (2014) reported, individuals from the sciences fields tend do value more creative problem solving, which may explain our results, since the instrument used evaluates insight skills, important to creative problem solving. Also, arts participants are better in the creative product (visual arts and plastic arts). We hypothesize that, since the arts field is connected to arts and design, it may provide experiences to its students that enable them to develop more creative works related to the visual and plastic arts. Past works also mentioned the close relationship between the creative environment and product (Ekvall, 1999; Isaksen \& Lauer, 2002; Kumiega, 1992; Miranda \& Almeida, 2008; Scritchfield, 1999; Selby, Shaw, \& Houtz, 2005).

Gender does not interact with the creative environment on the dependent variables, but age seems to have a small effect as a covariate on the interaction between the creative environment and creative product. Some authors found that gender and age influence creativity (e.g., Charyton, Hutchinson, Snow, \& Elliott, 2009), however others did not (e.g., Charyton \& Snelbecker, 2007; Cashdan \& Welsch, 1966).

No significant differences were found for the creative person, which corroborates that creativity thus exist in every one of us, regardless of the field of study/creative environment and gender, since gender does not have an effect on the interaction examined.

Generally, these results are interesting, showing that the creative environment thus indeed influence the creative process and product, but not the creative person. Consistent with this idea, Trnova (2015) stated that creativity in students depends on the context where they are embedded. Our findings suggest the importance that schools must give to their organization and goals, in order to redefine them in a way that promotes creativity. In higher education much is needed to change the current reproduction of knowledge to a more reflexive and creative way of thinking (Oliveira \& Alencar, 2007). As Trnova (2015, p.104) said, "it is desirable to encourage students to experiment, to innovate, not giving them all the answers but giving them the tools they need to find out what the answers might be or to explore new avenues" (p. 104). With this in mind, psychologists can help and promote, not only creativity, but other aspects, such as motivation, because the relationship between creativity and intrinsic motivation has been proven in previous researches (Jesus, Rus, Lens, \& Imaginário, 2013).

The present work presents some limitations worth considering, like the fact that two of the instruments used (CPS and CBI) are very recent in the Portuguese population, so there was not much background to compare results. Also, the fact that one of the instruments, the IPST, takes a little time to answer might have caused some distraction in the participants. We understand that in further studies there is the need to create a more balanced sample between the studied groups, being this one of the biggest limitations in the present study.

We suggest the need for further studies about the main concepts of this research and to enlarge the sample to other universities, specifically because of the small control effect accounted by age. Thus, we suggest to analyze this possible confounding variable in a further study. It also might be useful to replicate this research in other educational levels, as a way of understanding the importance of the creative environment in the development of future creative behaviors. Finally, we believe that it is fundamental to collect a sample that includes participants from different environments, such as the exact sciences, to further explore the possible differences between the different fields of study. We are aware of the possible limitation of studying such a complex variable focusing simply in the field of study of the participants, because many other variables may also influence this environment, such as different teachers and ways of teaching, the physical surroundings, the culture, among others. Despite these limitations, we believe this research can give us a glimpse of the relationship between the creative environment and the creative person, process, and product, highlighting the importance of promoting the creative environment to create a better creative life.

\section{References}

Alencar, E. S., \& Fleith, D. (2008). Criatividade pessoal: fatores facilitadores e inibidores segundo estudantes de engenharia. Magis: Revista Internacional de Investigación en Educación, 1(1), 113-126.

Alencar, E. S., \& Fleith, D. (2010). Criatividade na educação superior: fatores inibidores. Avaliação, 15(2), 201-206. doi: 10.1590/S141440772010000200011 
Amabile, T., Conti, R., Coon, H., Lazenby, J., \& Herron, M. (1996). Assessing the work environment for creativity. The Academy of Management Journal, 39, 1154-1184. doi: 10.2307/256995

Baer, J. (2011). Why teachers should assume creativity is very domain specific. The International Journal of Creativity \& Problem Solving, 21(2), $57-61$.

Bahia, S. (2008). Criatividade e universidade entrecruzam-se? Revista de Ciências de Educação, 7, 51-62.

Bahia, S., \& Nogueira, S. (2005). A criatividade dos estudantes universitários difere de área para área do conhecimento? Revista Recre@rte, 3, 1-34.

Batey, M., \& Furnham, A. (2006). Creativity, intelligence, and personality: A critical review of the scattered literature. Genetic, Social, and General Psychology Monographs, 132, 355-429. doi: 10.3200/MONO.132.4.355.-430

Beghetto, R., \& Kaufman, J. (2009). Intellectual estuaries: Connecting learning and creativity in programs of advanced academics. Journal of Advance Academics, 20, 296-324. doi: 10.1177/1932202X0902000205

Carson, D. (1999). Counseling. In M. Runco \& S. Pritzker (Eds.), Encyclopedia of Creativity (pp. 395-402). San Diego, CA: Academic Press.

Cashdan, S., \& Welsch, G. (1966). Personality correlates of creative potential in talented high school students. Journal of Personality, 34, 445454. doi: 10.1111/j.1467-6494.1966.tb01726.x

Charyton, C., Hutchison, S., Snow, L., Rahman, M., \& Elliott, J. (2009). Creativity as an attribute of positive psychology: The impact of positive and negative affect on the creative personality. Journal of Creativity in Mental Health, 4, 57-66. doi: $10.1080 / 15401380802708791$

Charyton, C., \& Snelbecker, G. (2007). General, artistic and scientific creativity attributes of engineering and music students. Creativity Research Journal, 19, 213-225. doi: 10.1080/10400410701397271

Cropley, A., \& Cropley, D. (2009). Fostering creativity: A diagnostic approach for Higher Education and Organizations. Cresskill, NJ: Hampton Press.

Csikszentmihalyi, M. (2009). Implications of a systems perspective for the study of creativity. In R. Sternberg (Ed.), Handbook of Creativity (pp. 313-338). Cambridge, United Kingdom: Cambridge University Press.

Davis, G. (1999). Barriers to creativity and creative attitudes. In M. Runco \& S. Pritzker (Eds.), Encyclopedia of creativity (pp. 165-174). San Diego, CA: Academic Press.

Dollinger, S. J. (2011). "Standardized minds" or individuality? Admissions tests and creativity revisited. Psychology of Aesthetics, Creativity, and the Arts, 5, 329-341. doi:10.1037/a0023659

Edwards, M., McGoldrick, C., \& Oliver, M. (2006). Creativity and curricula in higher education: Academics perspectives. In N. Jackson, M. Oliver, M. Shaw \& J. Wisdom (Eds.), Developing creativity in higher education (pp. 59-73). London, United Kingdom: Routledge.

Ekvall, G. (1999). Creative climate. In M. Runco \& S. Pritzker (Eds.), Encyclopedia of creativity (pp. 403-412). San Diego, CA: Academic Press.

Field, A. (2005). Discovering statistics using SPSS. London, United Kingdom: SAGE Publications.

Fryer, M. (2006). Facilitating creativity in higher education: A brief account of national teaching fellows' views. In N. Jackson, M. Oliver, M. Shaw \& J. Wisdom (Eds.), Developing creativity in higher education (pp. 74-88). London, United Kingdom: Routledge.

Garcês (2013). A multidimensionalidade da criatividade: a pessoa, o processo, o produto e o ambiente criativo no ensino superior (Doctoral dissertation). Madeira University. Madeira, Portugal.

Garcês, S., Pocinho, M., \& Jesus, S. (2012, julho). Inventário de comportamentos criativos: estudo preliminar de validação. Poster session presented at II Seminário Internacional "Contributos da Psicologia em Contextos Educativos”, Braga, Portugal.

Garcês, S., Pocinho, M., Jesus, S. N., Viseu, J., Imaginário, S., \& Wechsler, S. (2015). Estudo de validação da escala de personalidade criativa. Revista Iberoamericana de Diagnóstico e Evaluación Psicológica, 40(1), 17-24.

Guilford, J. P. (1950). Creativity. American Psychologist, 5, 444-454. doi: 10.1037/h0063487

Harrington, D. (1999). Conditions and settings/environment. In M. Runco \& S. Pritzker (Eds.), Encyclopedia of creativity (pp. 323-340). San Diego, CA: Academic Press.

Isaksen, S. (1995). Four P's in the pod: Some comments regarding the status and structure of the creativity domain and field. Retrieved from http://www. buffalostate.edu/orgs/cbir/readingroom/html/Isaksen-95.html

Isaksen, S., \& Lauer, K. (2002). The climate for creativity and change in teams. Creativity and Innovation Management, 11, 74-86. doi: $10.1111 / 1467-8691.00238$

Jesus, S. N., Morais, F., Pocinho, M., Imaginário, S., Duarte, J., Matos, F., \& Sousa, F. (2011). Escala da personalidade criativa: estudo preliminar para a sua construção. In A. S. Ferreira, A. Verhaeghe, D. R. Silva, L. S. Almeida, R. Lima, \& S. Fraga (Eds.), Actas do VIII Congresso Iberoamericano de Avaliação/Evaluación Psicológica, XV Conferência Internacional de Avaliação Psicológica: Formas e Contextos (pp. 18831891). Lisboa, Portugal: Sociedade Portuguesa de Psicologia.

Jesus, S. N., Rus, C., Lens, W., \& Imaginário, S. (2013). Intrinsic motivation and creativity related to product: A meta-analysis of the studies published between 1999-2010. Creativity Research Journal, 25, 80-84. doi: 10.1080/10400419.2013.752235

Jordanous, A. (2015, may). Four pppperspectives in computational creativity. Paper presented at the AISB 2015 Symposium on Computational Creativity, Canterbury, Kent, United Kingdom.

Keller-Mathers, S. (2011). Building passion and potential for creative learning in higher education. In A. Wright, M. Wilson \& D. Maclsaac (Eds.), Collected essays on learning and teaching (vol. IV, pp. 1-6). Windsor, ON: Society for teaching and learning in higher education.

Kozbelt, A., Beghetto, R., \& Runco, M. (2010). Theories of creativity. In J. Kaufman, \& R. Sternberg (Eds.), The Cambridge handbook of creativity (pp. 20-47). New York, NY: Cambridge University Press.

Kumiega, K. (1992). Creating systems to reinforce creativity. Retrieved from http://www.buffalostate.edu/orgs/cbir/readingroom/html/ Kumiega-92.html

Lee, H., \& Kim, K. (2010). Relationships between bilingualism and adaptive creative style, innovative creative style, and creative strengths among Korean American students. Creativity Research Journal, 22, 402-407. doi: 10.1080/10400419.2010.523409

Martim, M. (2007). Creativity: Ethics and excellence in sciences. New York, NY: Lexington Books.

Miranda, L., \& Almeida, L. S. (2008). Estimular a criatividade: o programa de enriquecimento escolar “Odisseia”. In M. F. Morais \& S. Bahia (Eds.), Criatividade: conceito, necessidades e intervenção (pp. 279-299). Braga, Portugal: Psiquilíbrios Edições.

Morais, F. (2001). Definição e avaliação da criatividade: uma abordagem cognitiva. Braga, Portugal, University of Minho.

Morais, F. (2003). Prova de resolução de problemas por insight. In M. Gonçalves, M. Simões, L. Almeida \& C. Machado (Eds.), Avaliação psicológica: instrumentos validados para a população portuguesa (pp. 166-177). Coimbra, Portugal: Quarteto Editora. 
Morais, F., \& Azevedo, I. (2009). Avaliação da criatividade como um contexto delicado: revisão de metodologias e problemáticas. Avaliação Psicológica, 8, 1-15.

Morais, M., F., Almeida, L. S., \& Azevedo, I. (2014). Criatividade e práticas docentes no ensino superior: como pensam os alunos de áreas curriculares diferentes? Revista AMAZônica, 12(2), 97-126.

Murdock, M., \& Keller-Mathers, S. (2008). Teaching and learning creatively with the Torrance Incubation Model: A research and practice update. International Journal of Creativity and Problem Solving, 18(2), 11-33.

O'Quin, K., \& Besemer, S. (1999). Creative products. In M. Runco \& S. Pritzker (Eds.), Encyclopedia of Creativity (pp. 413-422). San Diego, CA: Academic Press.

Oliveira, Z. M., \& Alencar, E. M. (2007). Criatividade na formação e atuação do professor do curso de letras. Revista Semestral da Associação Brasileira de Psicologia Escolar e Educacional (ABRAPEE), 11(2), 223-237.

Osborn, A. (1952). Wake up your mind: 101 ways to develop creativeness. New York, NY: Scribners.

Plucker, J., \& Renzulli, J. (2009). Psychometric approaches to the study of human creativity. In R. Sternberg (Ed.), Handbook of creativity (pp. 35-61). Cambridge, United Kingdom: Cambridge University Press.

Puccio, G., Treffinger, D., \& Talbot, R. (1995). Exploratory examination of relationships between creativity styles and creative products. Creativity Research Journal, 8, 157-172. doi: 10.1207/s15326934crj0802_4

Rhodes, M. (1961). An analysis of creativity. Phi Delta Kappan, 42, 305-310.

Ribeiro, R., \& Fleith, D. (2007). O estímulo à criatividade em cursos de licenciatura. Paideia, 17, 403-416. doi: 10.1590/S0103863X2007000300010

Runco, M. (2007). Creativity theories and themes: Research, development and practice. Boston, MA: Elsevier Academic Press.

Scritchfield, M. (1999). The creative person, product, process and press: The 4P's. Retrieved from http://www.buffalostate.edu/orgs/cbir/ readingroom/html/Scritchfield-99.html

Selby, E., Shaw, E., \& Houtz, J. (2005). The creative personality. The Gifted Child Quarterly, 49, 300-357. doi: 10.1177/001698620504900404

Simonton, D. (2004). Creativity as a constrained stochastic process. In R. Sternberg, E. Grigorenko \& J. Singer (Eds.), Creativity: From potential to realization (pp. 83-102). Washington, DC: American Psychological Association.

Soliman, S. (2005). Systems and creative thinking. Cairo, Egypt: Center for Advancement of Postgraduate Studies and Research in Engineering Sciences.

Sternberg, R., \& Lubart, T. (2009). The concept of creativity: Prospects and paradigms. In R. Sternberg (Ed.), Handbook of creativity (pp. 3-15). Cambridge, United Kingdom: Cambridge University Press.

Torrance, P. (1977). Creativity in the classroom; What research says to the teacher. Retrieved from ERIC database. (ED132593)

Trnova, E. (2015). Hand-on experiments and creativity. In M. F. Costa \& B. V. Dorrio (Eds.), Hands-on Science: Brightening our future (pp.103109). Funchal, Portugal: Hands-on Science Network.

Wallas, G. (1926). The art of thought. New York, NY: Harcourt, Brace and Company.

Ward, T., \& Kolomyts, Y. (2010). Cognition and creativity. In J. Kaufman \& R. Sternberg (Eds.), The Cambridge Handbook of creativity (pp. 93-112). New York, NY: Cambridge University Press.

Ward, T., Smith, S., \& Finke, R. (2009). Creative cognition. In R. Sternberg (Ed.), Handbook of creativity (189-212). Cambridge, United Kingdom: Cambridge University Press.

Wechsler, S. M. (2006). Validity of the Torrance Tests of Creative Thinking to the Brazilian Culture. Creativity Research Journal, $18,15-25$. doi: 10.1207/s15326934crj1801_3

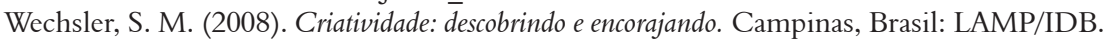

\section{Sobre os autores}

Soraia Garcês é licenciada, mestre e doutora em Psicologia da Educação pela Universidade da Madeira. Atualmente é investigadora do Centro de Estudos Regionais e Locais da Universidade da Madeira.

Margarida Pocinho é licenciada, mestre e doutora em Psicologia da Educação. Atualmente é professora auxiliar com Agregação em Psicologia na Universidade da Madeira, diretora do Programa de Doutoramento em Psicologia e membro do Painel de Avaliação da área da Psicologia da Fundação para a Ciência e a Tecnologia do Governo Português.

Saul Neves de Jesus é doutor em Psicologia da Educação pela Universidade de Coimbra. Atualmente é professor catedrático da Universidade do Algarve, diretor do curso de Doutoramento em Psicologia e presidente do Conselho Científico da Faculdade de Ciências Humanas e Sociais.

João Viseu é mestre em Psicologia Social e das Organizações pela Universidade do Algarve. Nesse momento, é estudante de doutoramento, em Psicologia, da Universidade do Algarve e bolsista de doutoramento da Fundação para a Ciência e a Tecnologia. 